\title{
Towards a Re-interpretation of Early Islamisation Processes in Southeast Asia
}

\author{
KATE WOODLEY
}

\section{Abstract}

This essay problematises gradualist conceptualisations of early Southeast Asian Islamisation processes, arguing that although such models offer plausible interpretations of Islamisation processes on a regional scale, they become problematic when applied to local cases of Islamisation. These problems arise primarily because local historical evidence 'resists' gradualism as the tempo of Southeast Asian Islamisation processes, as shown by the cases of Pasai and Gresik. This article proposes an alternative conceptualisation of local Southeast Asian Islamisation as a process occurring over long stretches of time punctuated by short periods of rapid change. Not only is this alternative conceptualisation of Islamisation's tempo more consistent with the evidence from Pasai and Gresik, it also provides an alternative framework for re-evaluating existing theories of the origins and nature of early Islamisation in Southeast Asia.

\section{Introduction}

In a 2006 paper on the historical origins of Islam in Southeast Asia, Southeast Asian Studies scholar Azyumardi Azra criticises Western scholars for their adherence to implicit Orientalist frameworks, arguing that these frameworks influence the nature of theorising on the origins of Islam in the region. ${ }^{1}$ Ironically, Azra goes on to characterise early Southeast Asian Islamisation as "an evolutionary process", thereby himself adhering to a hidden framework which views the 'natural' tempo of Islamisation as a gradual process, characterised

1 Azra Azyumardi, Islam in the Indonesian World: An Account of Institutional Formation (Bandung: Mizan, 2006), 2. 
by slow change over historical time. This essay seeks to problematise such conceptualisations of early Southeast Asian Islamisation, arguing that although gradualism provides a plausible framework for interpreting regional Islamisation processes, it fails to adequately explain local Islamisation processes. Through a re-examination of the historical evidence at the sites of Pasai and Gresik, this essay will contend that the tempo of early local Islamisation processes at these sites is better understood in terms of stasis, punctuated by abrupt change.

\section{Early Islamisation in Southeast Asia: Problems \& Possibilities}

In 2009, the US-based Pew Research Center's Forum on Religion \& Public Life released a report on the size and distribution of the world's global Muslim population. ${ }^{2}$ Contrary to longstanding popular beliefs that the Middle East - the 'spiritual' centre of Islam - held the majority of the world's Muslim population, the Pew Report revealed that only $20.1 \%$ of the global Muslim population reside in Middle East and North Africa. ${ }^{3}$ In contrast, the Pew report noted that $26 \%$ of the world's Muslims reside in Southeast Asia. ${ }^{4}$ Moreover, the report revealed that the world's most populous Muslim nation is located not in the Middle East, but in Southeast Asia. With more than 200 million of its inhabitants professed adherents of the Islamic faith, Indonesia's Muslim population easily eclipses that of any Middle Eastern country. ${ }^{5}$

In thus considering the importance of Islam to the Southeast Asia region, it is surprising to observe that the process of early Islamisation - the way by which individuals and groups become Muslim, and societies and cultures become 'Islamic', up until the mid- 15th CE - has been widely neglected by scholars of Southeast Asian Studies. ${ }^{6}$ To state that scholars have neglected Islamisation is not to argue that scholars have ignored questions of how Islam spread throughout Southeast Asia. Such questions have animated scholarly debate for more than a century. ${ }^{7}$ Rather, it is to emphasise that the process of Islamisation itself continues to be overlooked by scholars of Southeast Asia. ${ }^{8}$

\footnotetext{
2 Pew Research Center's Forum on Religion \& Public Life, Mapping the Global Muslim Population: A Report on the Size and Distribution of the World's Muslim Population (Washington D.C., 2009).

3 Ibid.,6.

4 Ibid.,12.

Ibid.,5.

Donald P. Little, ‘Review’, Middle East Journal 34, no.3 (Summer, 1980): 369.

7 For an overview of these debates, see Azra, Islam in the Indonesian World, 10-25.

8 This undertheorisation of Islamisation also extends to the broader field of Islamic Studies. See, for example, Ira Lapidus, 'Review', The American Historical Review 86, no.1 (February 1981): 187.
} 
The effect of this scholarly neglect is perhaps nowhere more evident than in relation to the tempo of Islamisation processes in Southeast Asia. That scholars of Southeast Asia have consistently interpreted Islamisation processes in gradualist terms is borne out by a survey of literature on the topic. For example, Azra nominates early Southeast Asian Islamisation as a slow "evolutionary process", while Houben visualises the process of Southeast Asian Islamisation as "like a slow, giant wave" ${ }^{9}$ Even the American anthropologist Clifford Geertz describes Southeast Asian Islamisation as "painfully gradual", despite admitting to the existence of little evidence to support this claim. ${ }^{10}$

The reasons why many scholars have chosen to adopt gradualism as the tempo of early Southeast Asian Islamisation are harder to discern, partly because - as Geertz indicates - they are not necessarily related to historical evidence. Suffice to say that the dominance of gradualism relates to scholarly understandings of Islamisation as a form of cultural change, a process seen by many scholars as temporally analogous to biological change. ${ }^{11}$ Cultural change is thus considered to be a process akin to neo-Darwinian evolutionism, a theory characterised by its claim that species evolve by gradual, constant transitions over long periods of time. ${ }^{12}$ One need only look to the predominance of claims of gradualism as the tempo of Southeast Asian Islamisation, to appreciate the underlying influence of neo-Darwinian evolutionism.

While gradualism may seem a natural choice for the tempo of early Southeast Asian Islamisation processes, it is by no means an inevitable one. During the 1970s, Gould and Eldredge challenged neo-Darwinian evolutionism's tenets of gradualism, by offering an alternative way of interpreting the fossil record. ${ }^{13}$ Gould and Eldredge noted that scientists had explained the absence of fossil evidence supporting the notion that evolution occurred through slow, constant transitions over long periods of time with reference to 'imperfections' in the preservation of fossils. ${ }^{14}$ However, because Gould and Eldredge proposed that

\footnotetext{
9 Azyumardi Azra, Islam in the Indonesian World, 6; Thomas Houben, "Southeast Asia and Islam", The Annals of the American Academy of Political and Social Science 588, no.l (July 2003), 153.

10 Clifford Geertz, The Religion of Java (Chicago: University of Chicago Press, 1976), 97. For further examples, see Michael Laffan, Islamic Nationhood and Colonial Islam: the Umma Below the Winds (New York: Routledge, 2003), 12; Merle Ricklefs, Mystic Synthesis in Java: A History of Islamization from the Fourteenth to the Early Nineteenth Century (Norwalk: Eastbridge, 2006), 11; B.J.O. Schrieke, Indonesian Sociological Studies Volume 2 (The Hague: W. Van Hoeve Ltd, 1957), 231.

11 Mesoudi, Whiten and Laland point to the widespread scholarly use of Darwinism evolutionary insights to explain cultural change, noting that Darwin himself used analogies with cultural change to explain biological evolutionism. Alex Mesoudi, Andrew Whiten and Kevin N. Laland, "Is Human Cultural Evolution Darwinian? Evidence Reviewed From the Perspective of The Origin of Species", Evolution 58, no.1 (2004), 1. 12 Niles Eldredge and Stephen Jay Gould, "Punctuated Equilibria: An Alternative to Phyletic Gradualism", in Models in Paleobiology, edited by TJM Schopf (San Francisco: Freeman, Cooper \& Co.,1972): 89.

13 Stephen Jay Gould and Niles Eldredge, "Punctuated Equilibria: the Tempo and Mode of Evolution Reconsidered", Paleobiology 3, no.2 (Spring 1977): 115-151.

14 Ibid., 116
} 
speciation occurs in rapid, punctuated time scales, occurring between periods of stasis, they argued that stasis in the fossil record reflected evidence that no change was occurring, rather than evidence of any lack of preservation. ${ }^{15}$

The importance of Gould and Eldredge's challenge to gradualism lies in its ability to provide us with alternative ways of understanding Southeast Asian Islamisation. This is not to argue that gradualism as the tempo of Southeast Asian Islamisation is entirely unsupported by the historical record. When viewed from a broad, regional perspective, the historical record does appear to support interpretations of early Southeast Asian Islamisation as a gradual process. Where problems arise, however, is when gradualist frameworks are applied to Islamisation on a local scale. Simply put, these problems emerge because the local historical record can 'resist' gradualist interpretations.

\section{Case Study: Pasai and Gresik}

Two examples of the way evidence for local Southeast Asian Islamisation resists or conflicts with gradualist interpretations derive from the sites of Pasai and Gresik.

Pasai is an area located in the north of the Indonesian island of Sumatra. Pasai has long been regarded as a key area for the reconstruction of early Islamisation in Southeast Asia, primarily due to the region's comparatively rich written and archaeological records.

One of the earliest pieces of historical evidence for the presence of Islam in Pasai derives from the traveller's account of the Venetian merchant, Marco Polo. In $1292 \mathrm{CE}$, Polo visited the Southeast Asia region en route to China. Among his many reports is a description of an island he called 'Java the Less' or 'Little Java', widely identified by modern scholars as Sumatra. ${ }^{16}$ Polo reported the presence of eight kingdoms on the island, including the Muslim-populated 'Ferlech' (identified by scholars as Perlak). According to Polo's description, "Saracen merchants" had converted the locals to Islam, although only the city dwellers had converted. ${ }^{17}$ Significantly, Polo identified the kingdom of Samara identified by modern scholars as Pasai-Samudra - as non-Muslim. ${ }^{18}$

The next piece of historical evidence from Pasai is a remarkably well-preserved gravestone purportedly belonging to a Muslim King of Pasai. According to Moquette, the inscriptions on the gravestone identified it as belonging to Malik

15 Ibid., 116-117.

16 G.B. Badelli Boni, The Travels of Marco Polo (New York: Harper \& Brothers Publishers, 1852 ), 248.

17 Ibid., 248.

18 Ibid.,249. 
al-Salih, who died in $1297 \mathrm{CE} .{ }^{19}$ Winstedt reports that the fifteenth century CE Malay chronicle Hikayat of Raja-Raja Pasai refers to al-Malik al-Salih, and his conversion to Islam. ${ }^{20}$

The historical record then falls silent until the Islamic tombstone of al-Malik alSalih's son, al-Malik al-Zahir, who died in $1326 \mathrm{CE}^{21}$

In 1345 CE, Ibn Battuta, a Moroccan Muslim traveller whose sojourns took in the frontiers of India, Southeast Asia, Central Asia and West Africa, visited what he identified as the Muslim Kingdom of Pasai. ${ }^{22}$ At Pasai, Ibn Battuta reports being received by the Muslim king al-Malik al-Zahir (grandson of al-Malik al-Salih), where he remained as a guest of the royal court. ${ }^{23}$

It is also noteworthy that Winstedt reports the presence of Islamic gravestones at Pasai, dating to $1407 \mathrm{CE}$, while Fatimi reports the recovery of another Islamic tombstone from $1428 \mathrm{CE}^{24}$

When contextualised within a regional perspective, evidence of Islamisation, such as the 11th century CE Champa inscriptions from Vietnam, the 11th/12th century Leran Stele from Gresik, the 13th century gravestone of Sultan Sulaiman bin Abdullah, bin al-Basir at Lamreh, and the 14th century CE Terengganu Stone, the Pasai evidence supports a gradualist interpretation of Islamisation. ${ }^{25}$ However, when considered on a local scale, the historical evidence of Pasai's Islamisation produces an altogether different, at times confused picture of a process alternately characterised by periods of stasis and abrupt change. Given these anomalies in understanding Pasai's Islamisation, it is instructive to examine how past scholars have attempted to reconcile these anomalies and 'gaps' in Pasai's local historical record within a gradualist framework.

19 As stated by S.Q., Fatimi, Islam Comes to Malaysia (Singapore: Malaysian Sociological Research Institute Ltd, 1963), 31.

20 R.O. Winstedt, "The Advent of Muhammadanism in the Malay Peninsula and Archipelago", Journal of the Royal Straits Branch of the Royal Asiatic Society 77 (December 1917): 171.

21 Elizabeth Lambourn, "Tombstones, Texts, and Typologies: Seeing Sources for the Early History of Islam in Southeast Asia", Journal of the Economic and Social History of the Orient 51, no.2 (2008): 258.

22 Ross, Dunn, The Adventures of Ibn Battuta: A Muslim Traveller of the Fourteenth Century (Berkley: University of California, 2005), xiii.

23 Ibid., 257.

24 R.O. Winstedt, "The Advent of Muhammadanism in the Malay Peninsula and Archipelago", 171; Fatimi, Islam Comes to Malaysia, 31-32.

25 For Champa, see Jacob Ramsay, "Cambodia and Vietnam" in Voices in Southeast Asia: A Contemporary Sourcebook. Compiled and Edited by Greg Fealy and Virginia Hooker (Singapore: Institute of Southeast Asian Studies, 2006), 33. For Lamreh, see Merle Ricklefs, A History of Modern Indonesia c.1200 (Basingstoke: Palgrave, 2002), 4. For the Leran and Trengganu material, see Fatimi, Islam Comes to Malaysia, 38-42 and 60-69. 
In a 1968 treatise on the origins of Islam in Southeast Asia, the Dutch scholar Drewes deliberates at length upon the case of Pasai and its evidence. ${ }^{26}$ Drewes accepts Ibn Battuta's reports that Pasai had become an Islamic kingdom by 1345 CE, but rejects Polo's account, citing the author's unreliability in correctly identifying locations. ${ }^{27}$ Instead, Drewes turns to Chinese accounts, arguing that they attest to Pasai's Islamisation prior to Polo's visit in 1292 CE. ${ }^{28}$

Of these Chinese sources, Fatimi conveys that shortly after a Chinese envoy met with a minister from the Kingdom of Pasai-Samudra in $1282 \mathrm{CE}$, two envoys bearing Arab-Muslim names were sent from Pasai-Samudra to China. ${ }^{29}$ Drewes takes these reports to affirm that Islamisation was already well underway before $1282 \mathrm{CE}$, thus pushing the date of the Islamisation process back into the distant past. ${ }^{30}$ It is important to note, however, that these Chinese sources do not identify these envoys as Muslim, nor do they identify Pasai as a Muslim kingdom. This circumstance alone does not disprove Drewes thesis, however, the important point to observe is that Drewes represents these Chinese sources as relatively unproblematic compared to Polo's report, whereas they arguably present equally challenging historiographical issues as evidence of Pasai's Islamisation.

Drewes faces further problems in explaining the 'gaps' in the historical record after $1297 \mathrm{CE}$. Interestingly, he neglects to offer any specific explanation of these 'gaps', although he makes extensive reference to evidential preservation issues in Southeast Asia. ${ }^{31}$ It is, however, significant to mention a scholarly debate surrounding the origins of Malik al-Salih's tombstone. In 1912, the Dutch scholar J.P. Moquette proposed that the stylistic features of the gravestone indicated that it was imported from Cambay, India in a period after the monarch's death - a theory subsequently accepted by many scholars, including Drewes. ${ }^{32}$ By arguing that the gravestone was not contemporaneous with the king's death, but imported at a later date, Moquette effectively removed the piece from Pasai's sequence of evidence.

Strikingly similar themes emerge in relation to the second case study of Gresik, a coastal locale situated in East Java, Indonesia.

\footnotetext{
26 G.W.J. Drewes, "New Light on the Coming of Islam to Indonesia", Bijdragen tot de Taal-, Land- en Volkenkunde 124, no.4 (1968): 433-59.

27 Ibid., 448-449. It is interesting to note that Drewes still apparently accepts Polo's identification of Perlak as Muslim.

28 Ibid.,447-448.

29 Fatimi, Islam Comes to Malaysia, 10.

3030 Drewes, 'New Light on the Coming of Islam to Indonesia', 448.

31 Ibid.,433-434.

32 Fatimi, Islam Comes to Malaysia, 32. Fatimi observes that Moquette left the date of the stones creation as 'unspecified'. For a brief discussion on the continued resonance of Moquette's claims, see Lambourn, "Tombstones, Texts, and Typologies: Seeing Sources for the Early History of Islam in Southeast Asia", 264.
} 
Gresik initially came to prominence in the 19th century CE, following the discovery of a gravestone dating from around the 15 th century $\mathrm{CE} .{ }^{33}$ According to inscriptions, the gravestone belonged to Maulana Malik Ibrahim, an individual believed to be an Arab missionary or merchant who came to Southeast Asia and died in $1419 \mathrm{CE} .{ }^{34}$ A second significant discovery occurred at a cemetery in the village of Leran, located near Gresik during the early twentieth century. In 1910, Moquette discovered a tombstone inscribed with the epitaph of a Muslim woman. ${ }^{35}$ Known as the 'Leran Stele', Moquette surmised a date of $1102 \mathrm{CE}$ for the stele, based upon his interpretation of the Arabic inscription. However, Ravaisse suggested $1082 \mathrm{CE}$ as a more accurate reading of the inscription. ${ }^{36}$

Like Pasai, the Gresik material supports a gradualist interpretation of Islamisation processes when set against regional evidence of Islamisation. However, when the Gresik material is considered on a local scale - separated as it is by several hundred years - gradualist interpretations of its local Islamisation begin to unravel.

Similar to the case of Pasai, the problematic temporal 'gap' between the Leran Stele and the gravestone of Maulana Malik Ibrahim prompted Moquette to re-evaluate the Leran Stele's position in the sequence of the Gresik evidence. Moquette's dating of the stele to the 11th and early 12th centuries CE reportedly raised problems in the scholar's understanding of Gresik's material sequence, such that he questioned its provenance as from Southeast Asia. According to Drewes: "Moquette...found it unacceptable (my emphasis) that this inscription, shallowly incised in a soft type of stone, should have defied the damp tropical climate for so many centuries, so that he doubted very much whether this stone actually belonged in Java (my emphasis). He was inclined to assume that it had been brought to Java from an arid region". ${ }^{37}$ Moquette thus sought to erase the stele from Gresik's material record by claiming that the item had been transported from another region, at a later period in time.

Moquette's decision to expunge the Leran Stele from Gresik's material record is particularly provocative in light of its implications for interpretations of local Islamisation. If the Leran Stele was indeed indigenous to the region - if it had survived the climatic conditions of Southeast Asia - then scholarly claims that evidence of gradual Islamisation processes had not been found because it had not survived are called into question.

\footnotetext{
33 Drewes, 'New Light on the Coming of Islam to Indonesia', 448.

34 Winstedt, "The Advent of Muhammadanism in the Malay Peninsula and Archipelago", 175. Winstedt notes that traditional Javanese literature records that Maulana Malik Ibrahim was one of eight or nine wali sanga, or saints, who brought Islam to Java.

35 Drewes, "New Light on the Coming of Islam to Indonesia", 454.

36 P. Ravaisse, "Le Inscription Coufique de Leran a Java", Tidschrift voor Indische Taal-Land-en Volkenkunde 65 (1925): 690, 701.

37 Drewes, "New Light on the Coming of Islam to Indonesia", 454
} 


\section{Evidence of Early Islamisation: A Question of Preservation?}

Claims of evidential preservation - or rather, lack thereof - abound throughout the literature on early Southeast Asian Islamisation. Ricklefs, for example, determines that "no definite conclusions (on the origins of Islam) have been possible because the records of Islamisation that survive are so few".$^{38}$ Similarly, Drewes expresses dismay over the paucity of evidence due to: "the devastating effect of the climate, the tropical rainfall, insects, mould and the remarkably quick rate of alluvial deposit, which together annihilate all trace of human activity as soon as man is no longer present". ${ }^{39}$

It is important to recognise that such assertions are not without foundation. In the particular case of Ricklefs complaint, paper-based documents plausibly survived the passage of time in fewer numbers, primarily due to the region's humid climatic conditions. ${ }^{40}$ However, whether such preservation issues affected the entire body of historical evidence is questionable. ${ }^{41}$ Lape, for instance, suggests that any lack of archaeological remains relates not to a lack of preservation, but to the lack of archaeological attention paid to the region..$^{42}$ Indeed, Lape's own discovery of dietary remains from around 1200 CE on Indonesia's Banda islands challenges claims that the environment "annihilated all trace of human activity" ${ }^{43}$

If preservation issues are not as acute as scholars have previously indicated, how then can we understand the persistence of claims that historical evidence once existed, but can no longer be seen? I would suggest that these claims are the direct result of Southeast Asian Islamisation conceptualised as an evolutionary process. Because many scholars of Southeast East Asia take the term 'evolution' to mean a slow, constant process of change, there exists an implicit expectation that historical evidence of Islamisation will reflect this process. However, because the local historical record frequently fails to meet these expectations, scholars explain these problematic 'gaps' in terms of evidential preservation problems, or in the case of Moquette, by excluding evidence from the local record altogether.

38 Rickleffs, A History of Modern Indonesia c.1200, 3.

39 Drewes, "New Light on the Coming of Islam to Indonesia", 433.

40 Whether written documents provide insight into Islamisation processes remains another question.

41 Peter Lape, "Archaeological Approaches to the Study of Islam in Island Southeast Asia", Antiquity 79,

no.306 (2005): 831.

42 Ibid., 831.

43 Ibid., 832-833. 
If we reconsider these so-called 'gaps' in the historical record, not as evidence of preservation problems, but as data representing Islamisation at work (or rather, not at work), our understanding of Islamisation as a process becomes open to new possibilities.

\section{Towards a Re-interpretation of Local Islamisation Processes at Pasai and Gresik}

Armed with a clearer understanding of how gradualist frameworks shape interpretations of evidence of local Islamisation processes, we may thus revisit our case study of Pasai and Gresik.

In terms of Pasai, I would suggest that the characterisation of its early Islamisation process as one of stasis, punctuated by short periods of abrupt change, accords better with the historical evidence currently available to us. Such an interpretation arguably better explains Pasai's evidential 'gap', than do claims that evidence once existed, but can no longer be seen due to preservation issues.

Here, it is relevant to recall Moquette's claim that the Pasai gravestone of alMalik al-Salih was imported from Cambay at an unspecified date after the king's death. Lambourn puzzles over the apparent 'blindness' of Moquette to the stylistic differences between gravestones of Cambay and that of al-Malik alSalih, arguing that Moquette's failure to see these differences "is very difficult to understand since these are so glaringly obvious" ${ }^{44}$ However, if we emphasise Moquette's gradualist pre-commitments, we begin to understand why - like the Leran Stele - the remarkable preservation of the gravestone, where no other local material had apparently survived, raised problems in Moquette's mind. By removing the gravestone from Pasai's indigenous sequence, Moquette was better able to reconcile why the gravestone had survived.

Reading Pasai's Islamisation in terms of this alternative tempo also lends itself to resolving Drewes problematique regarding the incongruity between Chinese sources and Marco Polo's report. The important point to observe is that, contrary to Drewes belief, neither historical account is intrinsically incompatible with the other. They only become incompatible when scholars view Islamisation as a slow, constant process across historical time. Because Drewes conceives of Islamisation in these terms, he takes the presence of Muslim envoys at Pasai as conclusive evidence that Islamisation processes were already under way by $1282 \mathrm{CE}$, thus refuting Polo's later reports that there were no Muslims at Pasai a

44 Lambourn, "Tombstones, Texts, and Typologies: Seeing Sources for the Early History of Islam in Southeast Asia", 264. 
decade later. That little or no Islamisation had occurred - despite the presence of Muslim envoys - until after $1292 \mathrm{CE}$, when Islamisation occurred abruptly, is a possibility that Drewes never seriously considers. His a priori assumptions about the tempo of Islamisation obstruct this possibility.

Moquette's insistence on expunging the Leran Stele from Gresik's historical record may be understood in similar terms. For Moquette, the problem posed by the 11 th/12th century stele was not strictly that the stone had survived the tropical climates of Southeast Asia, but that other expected evidence had seemingly not survived between the 12th and 15th centuries CE. Because Moquette envisaged Islamisation in gradualist terms, he sought to reconcile Gresik's evidential 'gap' by arguing that the Leran Stele - like the gravestone of al-Malik al-Salih - was imported from a foreign country at a later period. However, if we remove Moquette's broader assumptions about the gradualist tempo of local Islamisation in Southeast Asia, Gresik's Islamisation assumes a different appearance - one also characterised by long periods of stasis, punctuated by brief periods of abrupt, small scale Islamisation.

Although the cases of Pasai and Gresik are by no means conclusive, they are at least suggestive that there exist grounds for re-evaluating gradualist interpretations of early local Islamisation processes on a broader basis.

\section{Conclusion}

Clearly, there are no easy answers when it comes to understanding early Islamisation processes in Southeast Asia. Throughout this paper, I have argued that although gradualism offers a plausible framework for interpreting regional historical evidence of early Southeast Asian Islamisation, its utility as a tool for explaining local evidence of Islamisation is less certain. Because the local historical record can 'resist' gradualist interpretations of Islamisation, I have argued for a re-interpretation of the tempo of local Islamisation as a process characterised by stasis, punctuated by periods of rapid change. The value of understanding local Islamisation in these terms resides, not only in providing an alternative and arguably more nuanced reading of the local historical record, but also in providing an alternative framework for evaluating existing theories on the origins and spread of Islam throughout the Southeast Asian region. 